\title{
Trichilemmal carcinoma
}

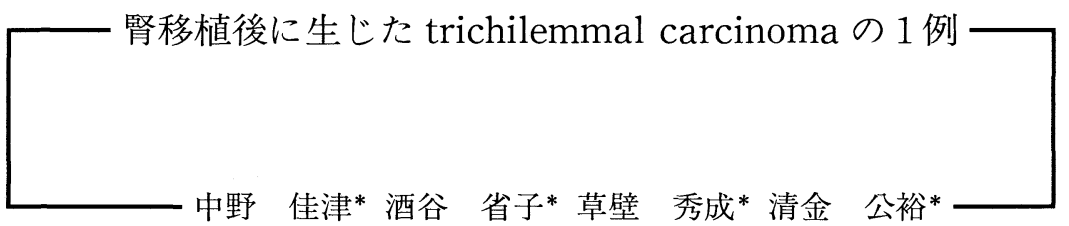

\section{Summary}

A 41-year-old man, who had received a kidney transplant in the U.S.A. because of chronic renal failure and been controlled with immunosuppresion therapy (azathioprine and cyclosporine) for about 4 years, developed an elastic-hard node $(1 \mathrm{~cm}$ in diameter) on the lower abdominal wall.

Histopathologically, an excisional biopsy of the tumor revealed that there was invasive growth of epithelial cells into the upper dermis. The peripheral cell layer of the tumor masses showed basophilic, palisading, and the centrally located cells showed atypical nuclei and a pale-staining cytoplasm which contained glycogen. A trichilemmal keratinization was observed. From these findings a trichilemmal carcinoma was made, and subsequently an extensive resection was performed. The incidence of malignant tumors following kidney transplantation is high. The graft survival rate is being improved, and thus the management of the malignant tumors following kidney transplantation is considered to be an important issue.

\section{緒言}

以前より，欧米では免疫抑制剂と悪性腫瘍の 関係について多数の報告がなされている。近年 本邦においても腎移植後の長期生着率の向上に 伴いその合併症としての悪性腫瘍発生に関する 報告が増加している。欧米では特に皮膚癌の発 生率が高く1) 4)，本邦においては消化器系の癌 が多いとされてきたが5) 7), 最近, 本邦において も皮膚癌に関する報告がみられるようになっ

* Kazu NAKANO, Shōko SAKATANI, Hidenari KUSAKABE, Kimihiro KIYOKANE: 大阪医科 大学皮膚科学教室

$$
た^{8) \sim 11)} \text { 。 }
$$

今回，我々は腎移植後，約 4 年間免疫抑制療 法中に発生した trichilemmal carcinoma の 1 例を経験したので，若干の文献的考察を加えて 報告する。

\section{症例}

症 例：41歳, 男性

初 診: 平成 5 年 4 月 1 日

家族歴：特記事項なし。

既往歴：慢性腎不全のため，平成 1 年 7 月ア メリカ合衆国にて死体腎移植施行。以後, プレ ドニゾロン $(10 \mathrm{mg} / \mathrm{day}) ，$ アザチオプリン（75 $\mathrm{mg} / \mathrm{day})$, シクロスポリン ( $250 \mathrm{mg} / \mathrm{day})$, フロ 
セミド (40mg/day), アテノロール(50mg/day) を約 4 年間連日内服中。

現病歴: 平成 5 年 1 月頃より恥骨部右側の腫 瘤に気付いた。腫瘤は次第に増大してきたため 当科受診。

現 症：恥骨部右側に $1.1 \times 0.9 \times 0.8 \mathrm{~cm} の$ 表面やや湿潤した黄紅色弾性硬の腫瘤が存在す る。潰瘍化は認められない（図 1 )。

臨床検査所見：血液一般検查では BUN；26 $\mathrm{mg} / \mathrm{d} l$ (正常值； $8 \sim 20 \mathrm{mg} / \mathrm{d} l$ )，尿酸； 10.2 $\mathrm{mg} / \mathrm{d} l$ (同；2.5 7.0mg/d $l$ )，クレアチニン； $1.6 \mathrm{mg} / \mathrm{d} l$ (同；0.5 1.3mg/d $l$ ) とやや上昇傾 向を示したが，腎機能は比較的良好に保たれて いた。また, 高脂血症を認める以外, 著変は認 めない。その他，血液を用いての G-banding 法 による染色体分析，P53遺伝子再構成，ras oncogene 解析, 腫瘍組織を用いての PCRによる human papilloma virus DNAの解析では異常
を認めなかったが，EB virus抗体価のうち VCA-IgG は2560倍 (正常值10倍未満) と著明に 上昇していた。

病理組織学的所見：表皮と連続して腫瘍巣は 下方に向かって不規則に増殖し，一部隔合して いる。また，角質囊腫様構造や毛包との連結す る部も認められ，一部では表皮・真皮との境界 が不鮮明で，真皮への侵潤を思わせる部位も認 められる(図 2)。腫瘍巣の辺縁部は主として好 塩基性の細胞，中央部は明調な細胞より構成さ れている。外毛根䩪性角化も散見される。中央 部の明調な細胞集塊では大小不同の核を有する 腫瘍細胞が増殖し, 分裂像, 個細胞角化も散見 される(図 3 )。明調な細胞はジアスターゼ消化 性 PAS 染色陽性を示した。以上より，trichilemmal carcinoma と診断し拡大再切除を 行った。

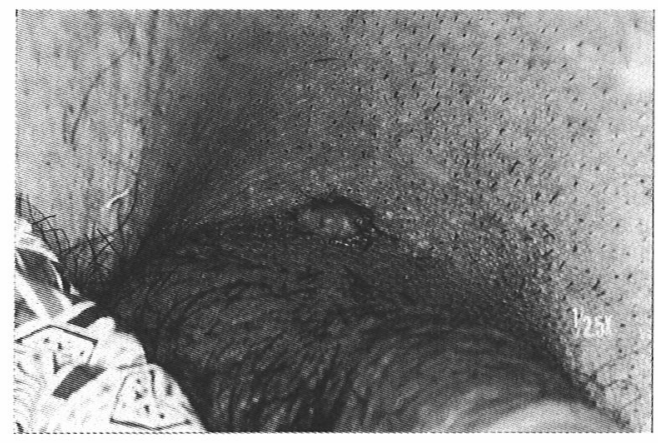

図 1.

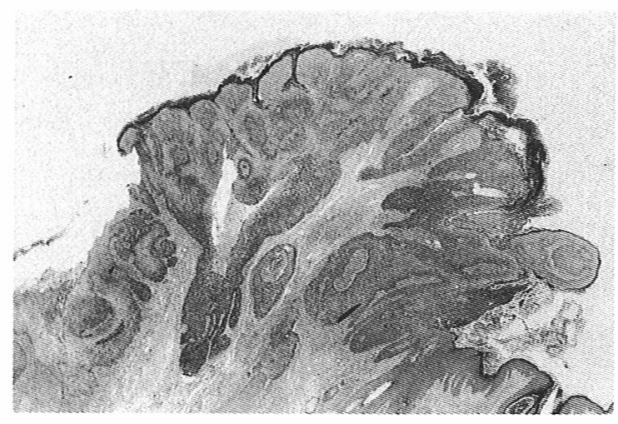

図 2 .

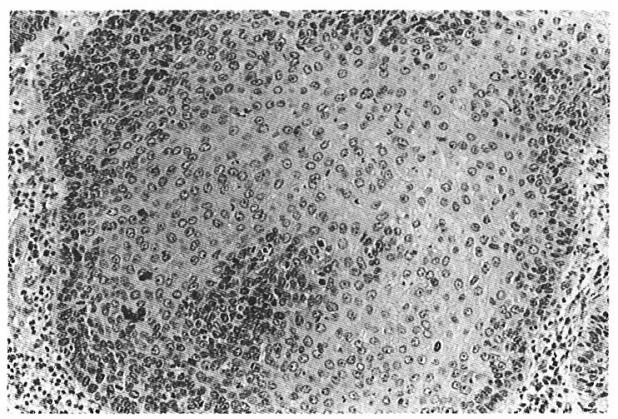

図3. 


\section{考按}

腎移植は慢性腎不全の根治療法であるが，免 疫抑制療法のもと長期生着症例が増加しつつあ る。Penn ${ }^{1)}$ は悪性腫瘍と臟器移植との関係につ いて1987年に Cincinnati Transplant Tumor Registry の集計を報告したが，免疫抑制状態で は特定の悪性腫瘍，特に皮膚悪性腫瘍・口唇癌 の発生率が上昇するとしている。その中で免疫 抑制剂を投与していない患者にみられる皮膚悪 性腫瘍との相違として，有棘細胞癌が最も多い こと，転移を起こしやすいことなどを揚げてお り，早期診断と十分な治療の必要性を述べてい る。また，免疫抑制剂の種類によって皮膚悪性 腫瘍の発生率と種類に相違が生じるという報告 もされている244。本邦における免疫抑制状態に おける悪性腫瘍発生頻度は欧米ほど高率ではな いが，皮膚悪性腫瘍の発生よりも消化器系内臟 悪性腫瘍が多いとされている5 本邦におけ る皮虐悪性腫瘍についての詳細な報告は我々が 検索した限りでは，有棘細胞癌が 3 例，悪性黒 色腫が 1 例あるのみで，trichilemmal carcinoma の発生例は自験例が初めてである。現 在, 発癌の機序として ${ }^{1)}, 1 ）$ 免疫抑制療法が リンパ細網系の免疫学的監視機構を抑制する,

2）免疫抑制剂自体が細胞に対して直接腫瘍原 性を示す，3）環境内にある発癌物質の効果を 薬剂が強める，4）腫瘍性ウイルスの感染を薬 剂が助長する，5）免疫抑制療法が腫瘍を攻撃 する感作リンパ球の働きを弱める，などが考え られている。

今回，我々の行った血液を用いての Gbanding 法による染色体分析，P53癌抑制遺伝 子再構成, ras oncogene 解析では異常を認め ず，腫瘍組織を用いてのコンセンサスプライ
マーPCR 法では，腫瘍性ウイルスである human papilloma virus DNA は検出されな かった。また, EB virus 抗体価のうち VCA-lgG が2560倍と著明に上昇していたことは非常に興 味あることであるが，発癌との関与については 明らかではなく，さらに検討を要すると思われ た。今後, 臟器移植後長期間の免疫抑制剂使用 症例の増加が予想され，免疫抑制剂と発癌のメ カニズムの解析が待たれるが，発癌についてハ イリスクグループであるため，早期発見のため の厳重な経過観察が必要と思われる。

\section{文献}

1) Penn, I., : Immunology Series 32. Cancers and Transplantation; Complication of Organ Transplantation, Toledo-Pereyra LH Ed, Marcel Dekker Inc, New York and Basel, 1987, 237251.

2) Penn, I., : Immunosuppression and Neoplasia, Cancers after Cyclosporine Therapy. Transplant Proc, 20 : 276-279, 1988.

3 ) Birkeland, S.A., : Cancer in Transplanted Patients-The Scandia-Transplant Material. Transplant Proc, 15 : 1071-1078, 1983.

4 ) Sheil, A.G.R., Flavel, S., Disney, A.P.S., et al. : Cancer Incidence in Renal Transplant Patients Treated With Azathioprine or Cyclosporine. Transplant Proc, 19: 2214-2216, 1987.

5 ) 吉村了勇, 岡隆宏, 大森吉弘, 他：腎移植後の悪 性腫瘍発生例に関する臨床的検討。移植，26： 160-165, 1991.

6 ）軍司祥雄，落合武徳，浅野武秀，他：腎移植患者 の悪性腫演と NK 活性·LK 活性. 日本臨床免疫学 会会誌, $13: 236-245,1990$.

7 ) 杉本久之：秋山暢夫：臟器移植後の発癌。臨床科 学, $24: 46-51,1988$.

8 ）美濃和茂，都築一夫，伊東重光，他：腎移植後に 悪性黒色腫を合併した 1 例. 移植, $19 ： 259-264$, 1984.

9 ) 小林ま巳子, 藤田優, 岡本昭二, 他：腎移植後の 皮膚有棘細胞癌の 1 例. 臨皮, $42 ： 151-155,1988$.

10）有田誠司，浅野武秀，榎本和夫，他：皮䖉癌にて 失った死体腎移植18年生着症例。日外会誌，89： 1726-1729, 1988.

11）兼重純明，近兼健一郎，比留間政太郎：腎移植者 に生じた有棘細胞癌の 1 例. 皮臨， $34 ： 919-921$, 1992. 